ISSN 2326-3350

\title{
Folin-Ciocalteau Reagent for Polyphenolic Assay
}

Gabriel A Agbor ${ }^{1,2}$, Joe A Vinson² and Patrick E. Donnelly ${ }^{2}$

Review Article

${ }^{1}$ Institute of Medical Research and Medicinal Plants Studies, P.O. Box 6163, Yaoundé, Cameroon

${ }^{2}$ Department of Chemistry, Loyola Science Center, University of Scranton, 204 Monroe Avenue, Scranton, PA, 18510 USA

\section{Abstract}

The chemistry of the Folin-Ciocalteu is described and two Folin assays (single and dual reagent) are described for the assay of phenols and polyphenols with respect to experimental detail and critically evaluated for pure compounds and for mixtures (plant extracts). The single reagent method was found to be more precise and sensitive. The problem of interferences in the Folin assay was evaluated for both methods. Interferences for the dual reagent methodology can be eliminated by a solid phase removal of phenols using a commercial resin (Oasys HLB) or polyvinylpyrrolidone resin (Polyclar AT). A new basic/acid hydrolysis combed with the Polyclar AT was used to measure the total phenols in a sample as previous methods measured only the phenolic groups not bound as ether or ester groups. A semi-automated method, microplate reader, is described as to the experimental procedure and applicability. Miscellaneous uses of the Folin assay including flow injection,urine analysis and a mixed standard are briefly described.

Keywords: Phenol, Folin-Cocialteu reagent, solid phase extraction

\section{*Corresponding Author:}

Gabriel A Agbor,

Institute of Medical Research and Medicinal Plants Studies,

P.O. Box 6163, Yaoundé, Cameroon

E-mail: agogae@yahoo.fr, agborgabriel@gmail.com

Received: June 24, 2014

Accepted: August 19, 2014

Published: August 21, 2014

Citation: Gabriel A Agbor, Joe A Vinson and Patrick E. Donnelly (2014)Folin-Ciocalteau Reagent for Polyphenolic Assay. Int J Food Sci Nutr Diet. 3(8), 147-156. doi: http://dx.doi.org/10.19070/2326-33501400028

Copyright:Gabriel A Agbor ${ }^{\circ}$ 2014. This is an open-access article distributed under the terms of the Creative Commons Attribution License, which permits unrestricted use, distribution and reproduction in any medium, provided the original author and source are credited.

\section{Description of Folin Ciocalteau Reagent}

The Folin-Ciocalteau (F-C) method of assay is the simplest method available for the measurement of phenolic content in products. It is a development of Folin Denis reagent used in the early 19th century for the determination of tyrosine in proteins [1]. F-C reagent can be prepared by dissolving $100 \mathrm{~g}$ sodium tungstate (VI) dihydrate and $25 \mathrm{~g}$ sodium molybdate (VI) dihydrate with $700 \mathrm{ml}$ distilled water, $100 \mathrm{ml}$ concentrated hydrochloric acid, and $50 \mathrm{ml}$ of $85 \%$ phosphoric acid to which is added $150 \mathrm{~g}$ of lithium sulphate hydrate. This reagent is very stable if protected from reductants and even when diluted if protected from light. For many years now, the F-C method of assay has been in use as a measure of polyphenol in natural products, and the basic mechanism is an oxidation/ reduction reaction with the phenolic group being oxidized and the metal ion reduced.

\section{Chemistry controlling the reaction with Folin-Ciocalteau reagent}

Folin-Ciocalteau phenol reagent consists of a mixture of the heteropoly acids, phosphomolybdic and phosphotungstic acids in which the molybdenum and the tungsten are in the $6+$ oxidation state. On reaction with a reductant, the molybdenum blue and the tungsten blue are formed and the mean oxidation state of the metals is between 5 and 6 .

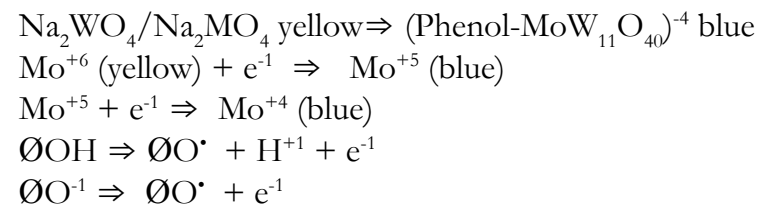

The above reaction is slow at acidic $\mathrm{pH}$ and faster when basic. It is very sensitive, precise but lack specificity. Singleton and Rossi [2] further improved the method with a molybdotungstophosphoric heteropolyanion reagent that reduced polyphenols more specifically with the $\lambda$ max for the product at $765 \mathrm{~nm}$.

$$
\begin{aligned}
& 3 \mathrm{H}_{2} \mathrm{O}-\mathrm{P}_{2} \mathrm{O}_{5}-13 \mathrm{WO}_{3}-5 \mathrm{MoO}_{3}-10 \mathrm{H}_{2} \mathrm{O} \\
& \text { and } \\
& 3 \mathrm{H}_{2} \mathrm{O}-\mathrm{P}_{2} \mathrm{O}_{5}-14 \mathrm{WO}_{3}-4 \mathrm{MoO}_{3}-10 \mathrm{H}_{2} \mathrm{O}
\end{aligned}
$$

To achieve meaningful, reliable and predictable results, some conditions such as proper volume ratio, optimal reaction time, and temperature for colour development, standard optical density, and use of a particular reference-standard polyphenol are required.

The improved method F-C reagent can be used by two principal procedures for the measurement of polyphenolic content i.e. as dual reagent $[2,3]$ and as single reagent $[4,5]$.

\section{Summary of Manual Dual Reagent Procedure [2]}

Up to $100 \mu \mathrm{L}$ of properly diluted sample in an organic water-miscible solvent with at least $6 \mathrm{~mL}$ of water $+0.5 \mathrm{~mL}$ of F-C reagent (Sigma); wait between $1-8 \mathrm{~min}$, add $1.5 \mathrm{~mL}$ of $\mathrm{Na}_{2} \mathrm{CO}_{3}$; mix and bring to $10 \mathrm{~mL}$ total volume with water; then measure absorbance $0.5-2 \mathrm{hr}$ later at $760 \mathrm{~nm}$ against a reagent blank and standards. 
The volume can be scaled down to conserve reagents.

\section{Summary of Single reagent Procedure $[4,5]$}

To $10-100 \mu \mathrm{L}$ of sample, add to a total volume of $1000 \mu \mathrm{L} 10$ fold diluted F-C reagent (Sigma) and read 10-20 min later at 750 $\mathrm{nm}$ vs. a reagent blank and standards.

Specific antioxidant classes and compounds detected by the F-C reagent

There are over 4000 citations of Folin in Chemical Abstracts and over 500 in PubMed as of December, 2008. Both the dual and the single Folin methods are good for the detection of a wide range of antioxidant compounds in a large variety of plants and plant-derived foods and beverages. The single reagent has been used for phenolic antioxidants from fruits $[4,6,7]$, vegetables $[8,9]$, cereals [7], fruit juices [10,11,12], caffeinated beverages [13,14], alcoholic beverages $[15,16]$ chocolate [17], herbs and spices [18,19] and plant extracts [20] by our group and other investigators. The major classification of antioxidant compounds: flavonols, flavones, flavanones, flavanols, proanthocyanidins, isoflavones, anthocyanins, phenolic acids are detected by the Folin methods.

\section{Procedure for the dual and single reagent assay methods for comparison}

Antioxidant compounds representing the different classes of polyphenols listed above were analyzed using both the dual and single reagent methods.

\section{Dual reagent assay}

The Singleton and Rossi [2] original method has been modified to suit different laboratory needs. The procedure was applied in our laboratory.

\section{Standard Preparation}

Preparation of catechin standard: Dissolve $2.9 \mathrm{mg}$ of catechin powder in $10 \mathrm{ml}$ of methanol, therefore resulting in a $1000 \mu \mathrm{M}$ solution. Keep in refrigerator when not in use. Prepare a new solution monthly.

\section{Standard Catechin Sample Preparation and Analysis}

Standard concentrations of catechin of $05,0 \mu \mathrm{M} 1,00 \mu \mathrm{M} 20,0 \mu \mathrm{M}$, $400 \mu \mathrm{M}$ and $800 \mu \mathrm{M}$, were prepared from the $(1000 \mu \mathrm{M})$ standard. Prepare standard curve by taking $40 \mu \mathrm{l}$ of catechin standard solution in to 6 different $10 \mathrm{ml}$ screw cap tubes, the first tube (blank) $40 \mu$ of nanopure water.

Add $800 \mu$ l of a 10 fold diluted Folin-Ciocalteau reagent in to each tube and mix well.

\section{Allow the tubes to stand for 5 minutes.}

Then add $800 \mu \mathrm{l}$ of $7 \% \mathrm{w} / \mathrm{v}$ sodium carbonate aqueous solution to each tube and mix well.

Make up volume in each tube with nanopure water $(360 \mu \mathrm{l})$ to $2 \mathrm{~mL}$, mix well, and allowed the tubes to stand for $2 \mathrm{hr}$.

Read absorbance at $760 \mathrm{~nm}$ against the blank using a UV-Visible spectrophotometer.

\section{Standard Curve Determination}

The absorbances of the standards were plotted against the standard concentrations. The regression line to this graph (Figure 1) was used to determine the catechin equivalent of the polyphenol concentration in the various samples analyzed.

\section{Folin assay of polyphenolic compounds (see Table 1)}

Polyphenolic compounds $(1 \mathrm{mM})$ were prepared in methanol. $40 \mu \mathrm{l}$ of sample was transferred in to a $10 \mathrm{ml}$ screw cap tube.

Add $800 \mu \mathrm{l}$ of a 10 -fold diluted Folin-Ciocalteau reagent in to the tube and mix well.

Allow the tube to stand for 5 minutes.

Then add $800 \mu \mathrm{l}$ of $7 \% \mathrm{w} / \mathrm{v}$ sodium carbonate aqueous solution

Figure. 1. Standard curve: Concentration of catechin against absorbance for the dual reagent method

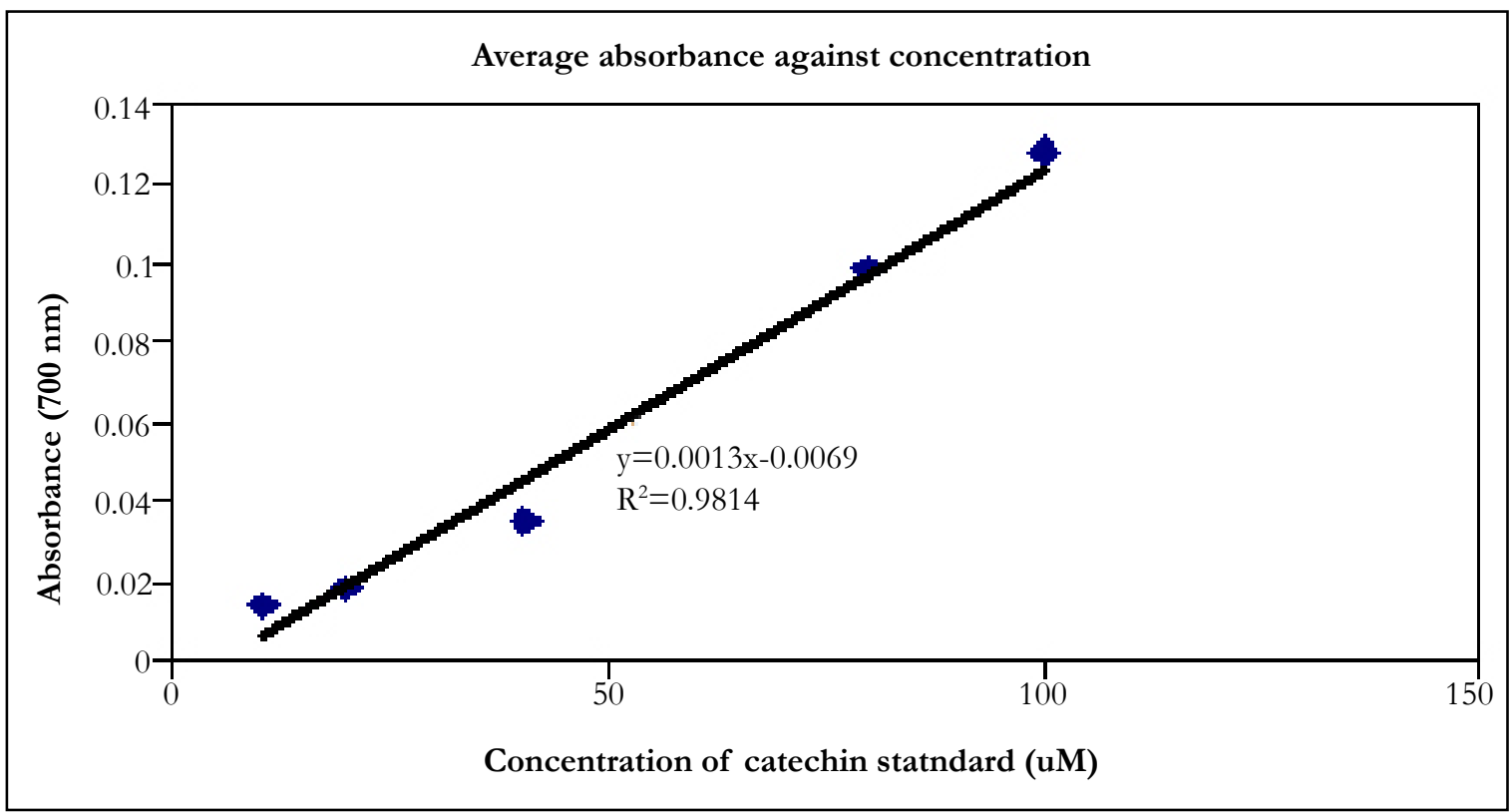


Table 1. Polyphenolic concentration ( $\mu \mathrm{M}$ catechin equivalent) of pure compounds and interferences as determined by single and dual reagent method

\begin{tabular}{|c|c|c|c|c|}
\hline $\begin{array}{l}\text { pure compounds and } \\
\text { interferences }\end{array}$ & Single reagent Polyphenol $(\mu \mathrm{M})$ & $\begin{array}{l}\text { Single reagent } \\
\text { precision }(\%)\end{array}$ & $\begin{array}{l}\text { Dual reagent Polyphenol } \\
(\mu \mathrm{M})\end{array}$ & $\begin{array}{l}\text { Dual re- } \\
\text { agent preci- } \\
\text { sion }(\%)\end{array}$ \\
\hline \multirow[t]{2}{*}{ Quercetin $1 \mathrm{mM}$} & 1132 & \multirow[t]{2}{*}{0.7} & 316.1 & \multirow[t]{2}{*}{2.07} \\
\hline & \pm 7.88 & & \pm 6.53 & \\
\hline \multirow[t]{2}{*}{ Kaemferol $1 \mathrm{mM}$} & 451 & \multirow[t]{2}{*}{2.33} & 164.5 & \multirow[t]{2}{*}{2.65} \\
\hline & \pm 10.51 & & \pm 4.35 & \\
\hline \multirow[t]{2}{*}{ Flavone $1 \mathrm{mM}$} & 200 & \multirow[t]{2}{*}{1.31} & 82.23 & \multirow[t]{2}{*}{6.615} \\
\hline & \pm 2.63 & & \pm 5.44 & \\
\hline \multirow[t]{2}{*}{ Neohesperidin $1 \mathrm{mM}$} & 159.3 & \multirow[t]{2}{*}{1.65} & 129.2 & \multirow[t]{2}{*}{7.58} \\
\hline & \pm 2.65 & & \pm 9.79 & \\
\hline \multirow[t]{2}{*}{ Naringin $1 \mathrm{mM}$} & 127.8 & \multirow[t]{2}{*}{4.11} & 193.4 & \multirow[t]{2}{*}{7.59} \\
\hline & \pm 5.25 & & \pm 14.68 & \\
\hline \multirow[t]{2}{*}{ Taxifolin $1 \mathrm{mM}$} & 545.6 & \multirow[t]{2}{*}{5.3} & 405.7 & \multirow[t]{2}{*}{11.66} \\
\hline & \pm 28.89 & & \pm 47.32 & \\
\hline \multirow[t]{2}{*}{ EGCG 1mM } & 1056 & \multirow[t]{2}{*}{1.49} & 591.5 & \multirow[t]{2}{*}{7.17} \\
\hline & \pm 15.76 & & \pm 42.43 & \\
\hline \multirow[t]{2}{*}{ Daidzein $1 \mathrm{mM}$} & 139.7 & \multirow[t]{2}{*}{4.51} & 98.77 & \multirow[t]{2}{*}{12.67} \\
\hline & \pm 6.30 & & \pm 12.51 & \\
\hline \multirow[t]{2}{*}{ Malvidin $1 \mathrm{mM}$} & 380.3 & \multirow[t]{2}{*}{13.81} & 195.7 & \multirow[t]{2}{*}{18.07} \\
\hline & \pm 52.53 & & \pm 35.36 & \\
\hline \multirow[t]{2}{*}{ Phloretin $1 \mathrm{mM}$} & 148.2 & 1.77 & 236.9 & 18.37 \\
\hline & \pm 2.62 & & \pm 43.51 & \\
\hline 3-hydroxyanthranilic & 2399 & 0.77 & 350.3 & 5.75 \\
\hline acid $2 \mathrm{mM}$ & \pm 18.39 & & \pm 20.13 & \\
\hline Caffeic acid $2 \mathrm{mM}$ & 913.3 & 2.59 & 360.3 & 14.64 \\
\hline & \pm 23.64 & & \pm 52.76 & \\
\hline Gallic acid $2 \mathrm{mM}$ & 709.1 & 1.85 & 577.2 & 0.66 \\
\hline & \pm 13.13 & & \pm 3.81 & \\
\hline Ferrulic acid $1 \mathrm{mM}$ & 203.2 & 2.78 & 252.6 & 12.7 \\
\hline & \pm 5.66 & & \pm 32.09 & \\
\hline Resveratrol 1mM & 479.9 & 0.93 & 243.4 & 17.21 \\
\hline & \pm 4.45 & & \pm 41.88 & \\
\hline Vitamin C (10mM) & 2098 & 0.97 & 1135 & 9.15 \\
\hline & \pm 20.41 & & \pm 103.89 & \\
\hline Tyrosine (10mM) & ND & ND & 218.8 & 2.74 \\
\hline & & & \pm 5.98 & \\
\hline $\begin{array}{l}\text { Glucose, fructose, } \\
\text { sucrose }(10 \mathrm{mM})\end{array}$ & ND & ND & ND & ND \\
\hline Albumin $(5 \mathrm{mg} / \mathrm{ml})$ & ND & ND & 493.4 & 0.55 \\
\hline & & & \pm 2.72 & \\
\hline
\end{tabular}

to the tube and mix well.

Make up volume in the tube with nanopure water $(360 \mu \mathrm{l})$ to $2 \mathrm{~mL}$ and mix well. In addition, allow to stand for $2 \mathrm{hr}$ at room temperature.

Absorbance was read at $760 \mathrm{~nm}$ against the blank using a UVVisible spectrophotometer.

The regression line $\mathrm{y}=\mathrm{mx}+\mathrm{c}$ from the standard curve was used to determine the polyphenolic concentration of the pure com- pounds.

where $\mathrm{y}=$ absorbance, $\mathrm{m}=$ gradient and $\mathrm{x}=$ concentration (unknown). This shows the different responses of the compounds.

Thus $\mathrm{x}=(\mathrm{y}+\mathrm{c}) / \mathrm{m}$

Example: Absorbance of quercetin $=0.410$. Based on the standard curve above,

$\mathrm{x}=(0.41+0.0069) / 0.0013=321 \mu \mathrm{M}$ 
Table 2. Free Polyphenolic concentration (mg/g catechin equivalent) of herbs and spices as determined by single and dual reagent method.

\begin{tabular}{|c|c|c|c|c|}
\hline Herbs and spices & $\begin{array}{l}\text { Single Reagent Poly- } \\
\text { phenol }(\mu \mathrm{M})\end{array}$ & $\begin{array}{l}\text { Single reagent preci- } \\
\text { sion }(\%)\end{array}$ & $\begin{array}{l}\text { Dual Reagent Poly- } \\
\text { phenol }\end{array}$ & $\begin{array}{l}\text { Dual reagent preci- } \\
\text { sion }(\%)\end{array}$ \\
\hline \multirow[t]{2}{*}{ P nigrum (leaves) } & 7.29 & \multirow[t]{2}{*}{4.12} & 22.91 & \multirow[t]{2}{*}{7.16} \\
\hline & \pm 0.30 & & \pm 1.64 & \\
\hline \multirow{2}{*}{$\begin{array}{l}\text { P nigrun (black pep- } \\
\text { per, seed) }\end{array}$} & 7.14 & \multirow[t]{2}{*}{1.12} & 22.04 & \multirow[t]{2}{*}{1.86} \\
\hline & \pm 0.08 & & \pm 0.41 & \\
\hline \multirow{2}{*}{$\begin{array}{l}\text { P umbellatum } \\
\text { (leaves) }\end{array}$} & 10.38 & \multirow[t]{2}{*}{1.45} & 39.73 & \multirow[t]{2}{*}{2.06} \\
\hline & \pm 0.15 & & \pm 0.82 & \\
\hline \multirow{2}{*}{$\begin{array}{l}\text { H cannabinus } \\
\text { (leaves) }\end{array}$} & 5.44 & \multirow[t]{2}{*}{1.47} & 12.76 & \multirow[t]{2}{*}{3.21} \\
\hline & \pm 0.08 & & \pm 0.41 & \\
\hline \multirow[t]{2}{*}{ R. heudelotti (seeds) } & 5.86 & \multirow[t]{2}{*}{3.92} & 15.08 & \multirow[t]{2}{*}{8.16} \\
\hline & \pm 0.23 & & \pm 1.23 & \\
\hline \multirow[t]{2}{*}{ S zenkeri (seeds) } & 7.97 & \multirow[t]{2}{*}{1} & 26.68 & \multirow[t]{2}{*}{1.54} \\
\hline & \pm 0.08 & & \pm 0.41 & \\
\hline \multirow[t]{2}{*}{ S zenkeri (bark) } & 5.38 & \multirow[t]{2}{*}{4.65} & 12.47 & \multirow[t]{2}{*}{10.75} \\
\hline & \pm 0.25 & & \pm 1.34 & \\
\hline \multirow{2}{*}{$\begin{array}{l}\text { A lepidophyllus } \\
\text { (seeds) }\end{array}$} & 6.34 & \multirow[t]{2}{*}{5.05} & 17.69 & \multirow[t]{2}{*}{13.05} \\
\hline & \pm 0.32 & & \pm 2.31 & \\
\hline \multirow[t]{2}{*}{ C mannii (seeds) } & 5.7 & \multirow[t]{2}{*}{7.89} & 14.21 & \multirow[t]{2}{*}{17.31} \\
\hline & \pm 0.45 & & \pm 2.46 & \\
\hline \multirow[t]{2}{*}{ I gabonensis (seeds) } & 4.69 & \multirow[t]{2}{*}{4.9} & 8.7 & \multirow[t]{2}{*}{14.14} \\
\hline & \pm 0.23 & & \pm 1.23 & \\
\hline \multirow[t]{2}{*}{ T vulgaris (seeds) } & 9.05 & \multirow[t]{2}{*}{2.54} & 32.48 & \multirow[t]{2}{*}{6.87} \\
\hline & \pm 0.23 & & \pm 2.23 & \\
\hline $\mathrm{G}$ africanum (seeds) & 7.72 & 5.83 & 25.23 & 9.75 \\
\hline & \pm 0.45 & & \pm 2.46 & \\
\hline$P$ nigrum (white pep- & 4.32 & 9.95 & 6.67 & 8.1 \\
\hline per, seeds)) & \pm 0.43 & & \pm 0.54 & \\
\hline
\end{tabular}

Figure. 2. Standard curve: Concentration of catechin against absorbance for the single reagent method

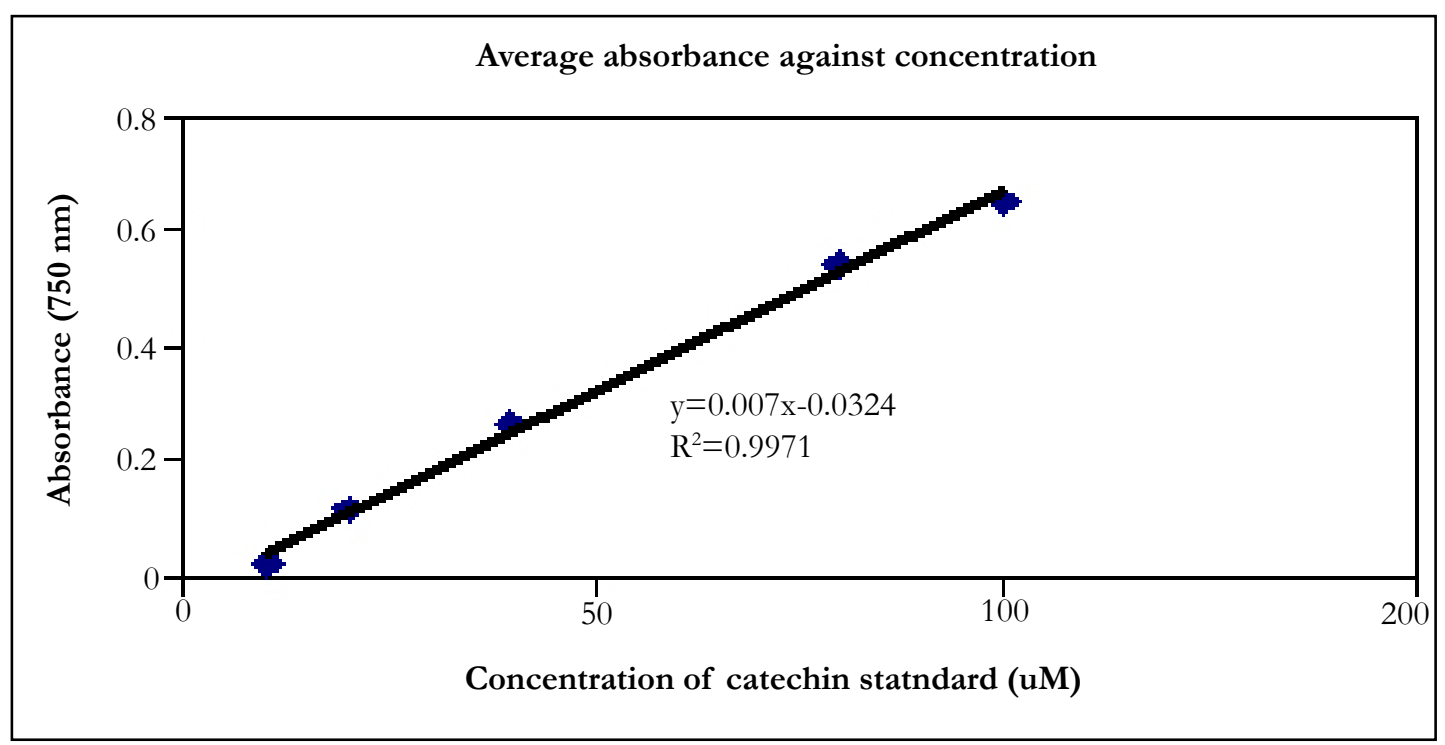

Single reagent assay

Standard Catechin Sample Preparation and Analysis.
Weigh $2.9 \mathrm{mg}$ of catechin powder in $10 \mathrm{~mL}$ of methanol making a solution of $1 \mathrm{mM}$. This is stable in the refrigerator at $4^{\circ} \mathrm{C}$ for at least one month.

Prepare standard curve by taking $0,10,20,40,50,100 \mu \mathrm{l}$ of the 
Figure 3. Solid phase extraction method to remove interferences prior to Folin assay for free polyphenols

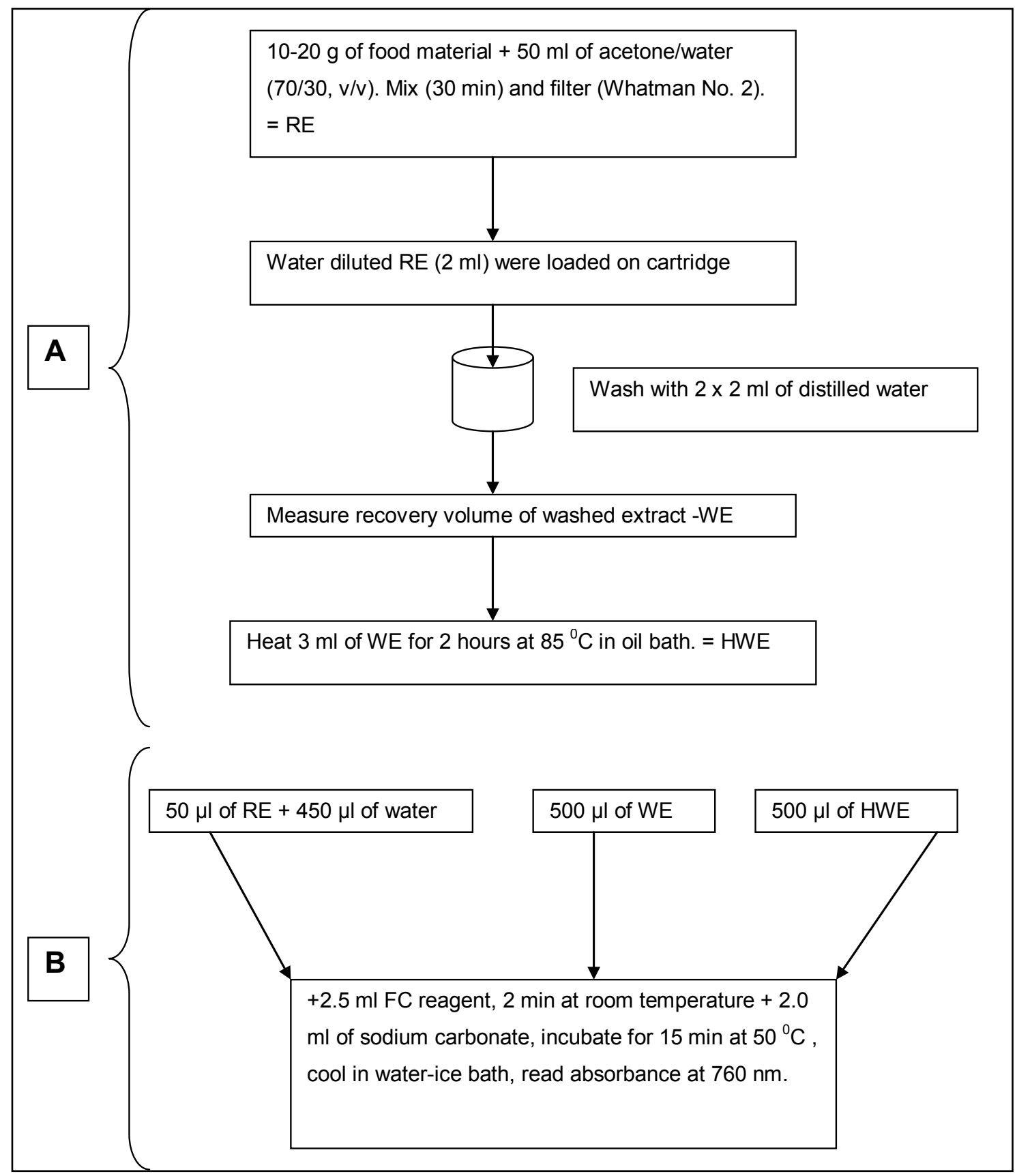

$1 \mathrm{mM}$ catechin solution to each of 6 micro cuvettes $(10$ to $100 \mu \mathrm{M}$ in the cuvette).

Add to a total volume of $1000 \mu \mathrm{L}$ a 5 -fold diluted Folin-Ciocalteau reagent $(\mathrm{FCR})$ and mix well. Allow the tubes to stand for 15 minutes and read absorbance at $750 \mathrm{~nm}$. The colour is stable for 30 minutes.

\section{Standard Curve Determination}

The absorbance was plotted against the standard volumes $(\mu \mathrm{l})$. The regression line to this graph is used to determine the catechin equivalence in the various samples to be analyzed.

\section{Folin assay of polyphenolic compounds}

Polyphenolic compounds $(1 \mathrm{mM})$ were prepared in methanol. $40 \mu \mathrm{l}$ of the sample was transfer in to a micro cuvette.

$1 \mathrm{ml}$ of a 5 -fold diluted Folin-Ciocalteau reagent was added and mixed by inversion.
The cuvette was allowed to stand for 15 minutes and the absorbance read at $750 \mathrm{~nm}$ in a UV spectrophotometer against a reagent blank.

The regression line of the standard curve $(y=m x+c)$ was used to determine the polyphenolic concentration $(\mu \mathrm{M})$ in the various samples analyzed.

$\mathrm{y}=$ absorbance, $\mathrm{m}$ = gradient, $\mathrm{x}$ is the concentration to be determined.

Thus Polyphenolic concentration $(\mathrm{x})=(\mathrm{y}+\mathrm{c}) / \mathrm{m}$

Example using quercetin $(1 \mathrm{mM})$, Volume of Folin reagent 1000 $\mu \mathrm{l}$, volume of quercetin $=40 \mu \mathrm{l}$, total volume of the reaction mixture $=1040 \mu \mathrm{l}$, Absorbance $=0.271$. Then concentration of quercetin $=[(0.271+0.0324) / 0.007)] \mathrm{x}(1040 / 40)=1127 \mu \mathrm{M}$ cat echin equivalent (since catechin was used as the standard). 
Figure 4. Polyclar solid phase extraction and basic hydrolysis prior to Folin assay for total polyphenols

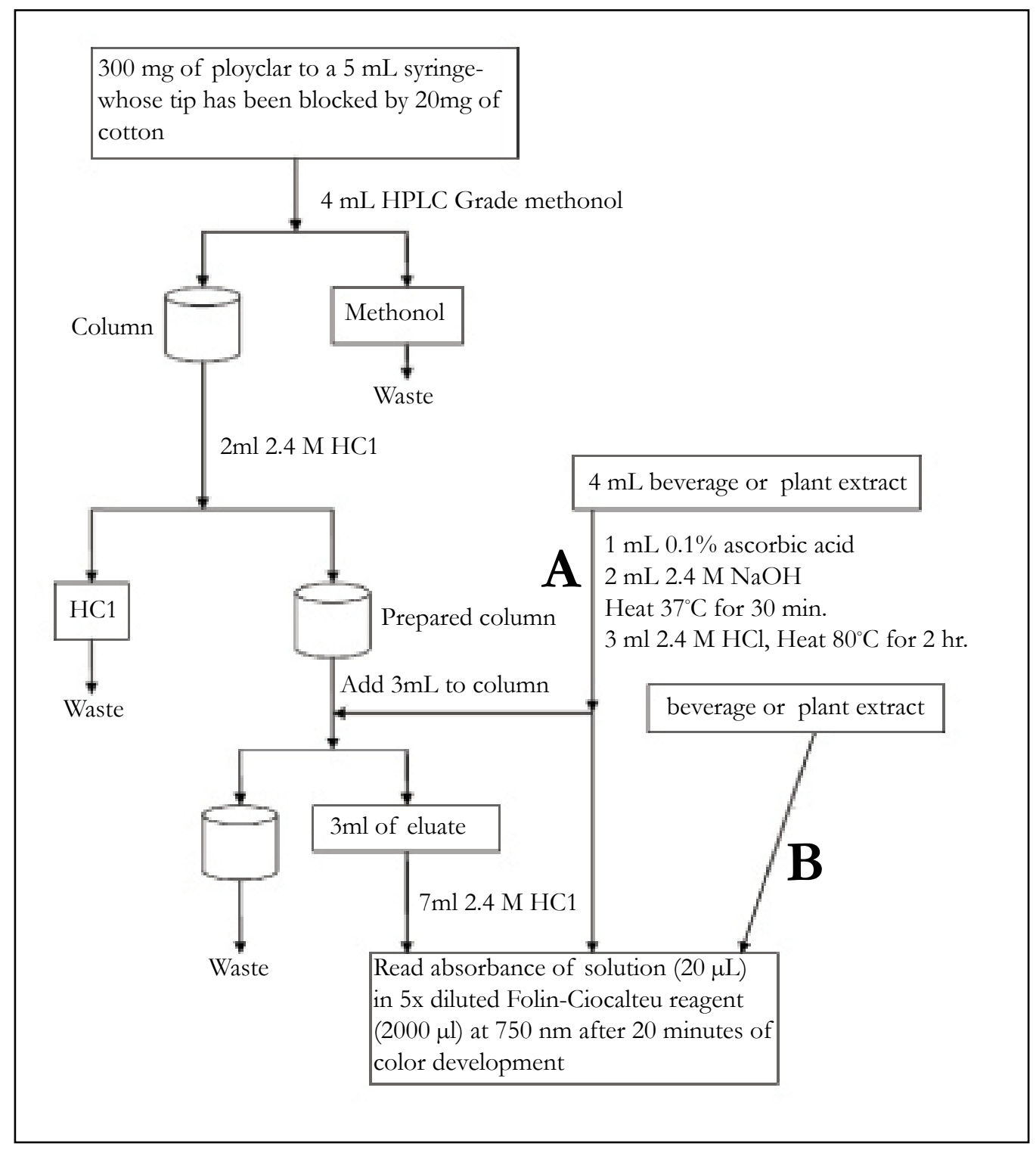

Free Polyphenolic concentration of herbs and spices by single and dual reagent (Table 2)

In order to analyze for polyphenol in plant material or natural products, there has to be extraction.

Extraction procedure: Samples were cleaned with tap water, air dried at room temperature, or at low temperature $\left(40^{\circ} \mathrm{C}\right)$ in an oven.

Blend samples in a blender then lyophilized to constant weight (48 hours).

The samples in duplicate is then extracted with methanol by dissolving $100 \mathrm{mg}$ of plant material in methanol and make final volume to $10 \mathrm{ml}$. Heat at $90^{\circ} \mathrm{C}$ for two hours with intermittent shaking. Allow to cool, then centrifuge at $3000 \mathrm{rpm}$ and filter. The filtrate is then analyzed by either the single or dual reagent method for polyphenolic assay. Extracts can be stored at $-20^{\circ} \mathrm{C}$ until required for subsequent polyphenolic assay.

\section{Comparison of the two methods for pure polyphenols and samples}

The two methods (single and dual reagent) may be compared using four criteria; precision, analysis time, sensitivity and selectivity (interferences). The single step blank reads 0.000 and the two step blank reads 0.009 , both vs. water as 0.000 . Four standards were measured in quadruplicate and the simple Folin precision was 3\% and the two-step Folin 5\%. The time for analysis is 25 minutes for the single step and 1.6 hours for two-step method for a preparation of a standard curve. For precision of pure compounds, the single reagent averaged $3.1 \%$ and the dual $9.7 \%$. The dual had a significantly poorer precision, $\mathrm{p}<0.001$. For the herbs the single reagent average precision was $5.2 \%$ and the dual $8.3 \%, \mathrm{p}<0.05$. So the single reagent with fewer steps and pipetings had significantly better precision. The slope of the standard curve is a measure of sensitivity. The slope was about 2.5 times higher (accounting for $2000 \mathrm{uL}$ total volume in the dual method and $1000 \mathrm{uL}$ for the single procedure) for the single reagent procedure indicating a greater sensitivity. There was no interference for glucose, tyrosine and albumin with the single reagent while tyrosine and albumin gave a positive Folin response with the dual reagent. The average 
for the herbs was almost 3 times higher for the dual reagent, 17.7 $\mathrm{mg} / \mathrm{g}$ vs. 6.7 for the single reagent $(\mathrm{p}<0.001)$. This is probably indicative of the dual reagent method being more prone to amino acid and protein interference.

\section{Other Dual Reagent Applications}

Microplate reader for polyphenols [21]

\section{Instrument}

- Multi-detection microplate reader (Synergy HT, BioTek) (see Equipment Setup)

- $\quad$ Mixer mill disruptor with adaptor sets for $2 \mathrm{ml}$ tubes (Qiagen tissue lyser) or mortar and pestle

\section{Reagent Setup}

Methanol Prepare solution of 95\% (vol/vol) methanol in water. Sodium carbonate Prepare solution of $700 \mathrm{mM} \mathrm{Na}_{2} \mathrm{CO}_{3}$ in water.

Gallic acid Prepare solutions of $50 \mathrm{mM}-2.5 \mathrm{mM}$ gallic acid in $95 \%$ (vol/vol) methanol.

\section{Equipment Setup}

Microplate reader Set up the microplate reader to run an endpoint absorbance read at $765 \mathrm{~nm}$ (at room temperature: $\sim 20^{\circ} \mathrm{C}$ ).

\section{Procedure}

\section{$\mathrm{F}-\mathrm{C}$ extraction and assay}

1) Harvest plant material (approximately $20 \mathrm{mg}$ ) in screw-capped tubes and freeze immediately in liquid nitrogen and store at$80^{\circ} \mathrm{C}$. Samples can be stored at $-80^{\circ} \mathrm{C}$ for $1-2$ months. Extract with methanol and collect the supernatant in a fresh $2 \mathrm{ml} \mathrm{micro-}$ tube.

2) To homogenize the tissue, place three tungsten carbide leads and $2 \mathrm{ml}$ of ice-cold $95 \%(\mathrm{v} / \mathrm{v})$ methanol in each sample tube and insert samples into pre-cooled Teflon adaptors. Homogenize tissue for 5 minutes at $30 \mathrm{~Hz}$. If a mixer mill is not available, tissue can be homogenized in an ice-cold mortar and pestle.

3) Remove tungsten carbide leads with magnet and incubate the samples at room temperature for 48 hours in the dark.

4) Centrifuge the samples $(13,000 \mathrm{~g}$ for 5 minutes at room temperature) and collect the supernatant in a fresh $2 \mathrm{ml}$ microtube.

5) Add $100 \mathrm{ml}$ of each sample supernatant, standard or $95 \%$ (vol/ vol) methanol blank to duplicate $2 \mathrm{ml}$ microtubes.

6) Add $200 \mathrm{ml} \mathrm{10 \%} \mathrm{(vol/vol)} \mathrm{F-C} \mathrm{reagent} \mathrm{and} \mathrm{vortex} \mathrm{thoroughly.}$ The $\mathrm{F}-\mathrm{C}$ reagent should be added before the alkali to avoid the air-oxidation of phenols.

7) Add $800 \mathrm{ml} 700 \mathrm{mM} \mathrm{Na}^{2} \mathrm{CO}_{3}$ into each tube and incubate the assay tubes at room temperature for $2 \mathrm{~h}$.

8) Transfer $200 \mathrm{ml}$ sample, standard or blank from the assay tube to a clear 96-well microplate and read the absorbance of each well at $765 \mathrm{~nm}$.
Free phenolics calculation

9) Calculate a standard curve from the blank-corrected absorbance at $765 \mathrm{~nm}$ of the gallic acid standards. Calculate phenolics as gallic acid equivalents using the regression equation between gallic acid standards and absorbance at $765 \mathrm{~nm}$.

\section{Solid Phase Extraction Method to remove interferences [22]}

\section{Sample Preparation.}

All of the food products (apple purees and juices) were purchased at a local market and stored at $4^{\circ} \mathrm{C}$ until analysis (Figure 3).

\section{Material and Solvent Standards.}

All solvents were of the highest analytical grade. Reference compounds were from Extrasynthèse (Genay, France) and reagents and solvents from Sigma-Aldrich Chimie (Saint Quentin Fallavier, France).

Cartridges. The SPE cartridge was an Oasis HLB from Waters (Milford, MA). HLB is an acronym for hydrophilic-lipophilic balance, the solid-phase being a copolymer [poly(divinylbenzene-co$\mathrm{N}$-vinylpyrrolidone)]. After any analysis, the cartridge was conditioned with $4 \mathrm{~mL}$ of pure methanol and rinsed with 2 X $4 \mathrm{~mL}$ of water.

\section{Preparation of Raw Extracts.}

Purees or juices $(10-20 \mathrm{~g})$ were homogenized with the same extraction solution (acetone/water, 7/3, v/v) for $30 \mathrm{~min}$. Mixture supernatants were then recovered by filtration (Whatman, England) and reconstituted the raw extracts (REs).

\section{Separation of Polyphenol and Other Water-Soluble Compo- nents by Solid-Phase Extraction.}

REs were added with distillated water to reduce the proportion of acetone to $7 \%$. Diluted REs $(2 \mathrm{~mL})$ were settled on an Oasis cartridge (Waters). Interfering water-soluble components (reducing sugars, ascorbic acid) were recovered with $2 \times 2 \mathrm{~mL}$ of distillated water. The recovered volume of the washing extract (WE) was carefully measured.

\section{Elimination of Vitamin C from WE.}

Heating was carried out on the washing extract $(3 \mathrm{~mL})$ for $2 \mathrm{~h}$ at $85^{\circ} \mathrm{C}$ (Fisons Haake N2 oil bath) and led to the heated washing extract (HWE).

\section{Folin-Ciocalteu Assay.}

All extracts (RE, WE, and HWE) were submitted to the FolinCiocalteau method (Singleton and Rossi, 1965), adapted, and optimized: A $2.5 \mathrm{~mL}$ sample of water-diluted Folin-Ciolcateu reagent $(1 / 10)$ was added to the different extracts. The mixture was incubated for $2 \mathrm{~min}$ at room temperature, and $2 \mathrm{~mL}$ of sodium carbonate $\left(75 \mathrm{gL}^{-1}\right)$ was added. The mixture was incubated for 15 min at $50^{\circ} \mathrm{C}$ and finally cooled in a water-ice bath. The specific absorbance at $760 \mathrm{~nm}$ was immediately measured.

Determination of Polyphenols and Vitamin C and Expression of the Results. 
Total polyphenols, determined by subtracting gallic acid equivalent from RE from that of WE, were expressed as mg of gallic acid $/ 100 \mathrm{~g}$ of product (slope $=0.012, \mathrm{R}^{2}=0.99$ ). Linearity was obtained between 50 and $500 \mathrm{mg} / \mathrm{L}$ corresponding to absorbance values between 0.1 and 0.6. Vitamin C, determined by subtracting ascorbic acid equivalent from WE from that of HWE, was expressed as $\mathrm{mg} / 100 \mathrm{~g}$ of product (slop $\left.=0.008, \mathrm{R}^{2}=0.99\right)$. Linearity was obtained between 50 and $1000 \mathrm{mg} / \mathrm{L}$ corresponding to absorbance values between 0.1 and 0.6.

This procedure is designed to separate free polyphenols from Folin interferences. The average recovery of 16 polyphenols following methanol elution of the solid phase column was $86 \pm 16 \%$. Ascorbic acid was completely eliminated by the heating step of the water wash. With the dual reagent a maximum of $7 \%$ of organic solvent (acetone or methanol) was allowed without interference with the Folin reaction.

Acid hydrolysis of herbs, fruits and vegetables for total polyphenol analysis [5]

In the plant polyphenols are often bound to sugars with an ether linkage or to carboxylic acids with an ester bond. Some or all of these bonds could be broken during digestion in the gastrointestinal tract and thus be available for absorption into the body. Thus almost all of the published literatures on polyphenol compound concentrations in foods and beverages and also antioxidant activity assays with Folin and other methods have underestimated the amount of phenols and often mislabeling their assay as total polyphenols. We used a modification of procedure first published in 1992 [23].

\section{Procedure}

A freeze dried sample of fruit or vegetable (50 to $500 \mathrm{mg}$ ) or an aliquot of a fruit or vegetable-derived beverage is added to $8 \mathrm{ml}$ of $50 \%$ methanol/water containing $1.2 \mathrm{M}$ hydrochloric acid in a screw-capped plastic tube and heated for 2 to 3 hours at 950C with vortexing every 30 minutes for solid samples. The solution was then allowed to cool to room temperature and then quantitatively transferred and diluted to $10 \mathrm{ml}$ with water in a volumetric flask. This solution is then used to determine total polyphenols in the sample by the single reagent Folin procedure. Free polyphenols can done by the same procedure except that no $\mathrm{HCl}$ was used in the analysis.

\section{Polyclar procedure to remove interferences and measure free and total polyphenols}

One of the faults of the acid hydrolysis procedure for total polyphenols is that it is not optimized for phenolic acids which are a class of highly prevalent non-flavonoid polyphenols in plants primarily in an ester form. Natella published an alkaline hydrolysis method which liberates caffeic acid from chlorogenic acid (ester form) in yields of $97 \pm 3 \%$ in coffee [24]. This hydrolysis procedure gave equivalent results to the commonly used but expensive glucuronidase/sulfatase enzyme method. Our procedure incorporates a basic hydrolysis with ascorbate present to stabilize the polyphenols and an acidification and heating to destroy the ascorbate and hydrolyze any leftover phenol groups still with an ether or ester linkage [22]. Free phenolic groups can be assayed by Folin prior to hydrolysis and interferences determined after polyphenol treatment described in the following procedure. Solid samples are extracted with $50 \%$ methanol as in our herbs, vegetables and fruits procedure previously described. The solution that is added to polyclar must contain no more than $10 \%$ methanol so $50 \%$ extracts need to be diluted $5 \mathrm{X}$ with water. We tested 1000 $\mu \mathrm{M}$ solutions of the following pure compounds representative of 6 classes of polyphenols: Ferulic acid (phenolic acid), Quercetin (flavonol), (+)-Catechin (flavanol), Naringenin (flavanone), Taxifolin (flavonone), Genistein (isoflavone), and Malvidin 3-Oglucopyranoside (anthocyanin). All were 100\% absorbed by the polyclar.

\section{Polyclar Procedure}

(1) Into a clean, dry $10 \mathrm{~mL}$ mailing tube pipette $4 \mathrm{~mL}$ of solution to be analyzed

(2) Into the same tube add $1 \mathrm{~mL} 0.1 \%$ ascorbic acid solution, and $2 \mathrm{~mL}$ of $2.4 \mathrm{M} \mathrm{NaOH}$ solution.

(3) Vortex and incubate this tube with cap on at 37 degrees $\mathrm{C}$ for $30 \mathrm{~min}$.

(4) Remove the tube and allow it to cool.

(5) Add $3 \mathrm{~mL}$ of $2.4 \mathrm{M} \mathrm{HCl}$ solution (final volume is now $10 \mathrm{~mL}$ ) vortex or shake.

(6) Heat at 80 degrees $\mathrm{C}$ for $2 \mathrm{hr}$.

(7) Remove from heat and let cool.

(8) Prepare polyclar column:

- In a clean dry $5 \mathrm{~mL}$ syringe

- Block the tip of the column with $20 \mathrm{mg}$ for cotton

- On top for the cotton add $300 \mathrm{mg}$ for polyclar (Polyclar VT, ISP Technologies)

- Prep the column by running $4 \mathrm{~mL}$ of HPLC Grade methanol through it

- Add $2 \mathrm{~mL}$ of $2.4 \mathrm{M} \mathrm{HCl}$ to equilibrate the column

(9) Add $3 \mathrm{~mL}$ of hydrolyzed sample to the column and allow dripping through, making certain to collect $3 \mathrm{~mL}$ of eluate.

(10) Make the final volume $10 \mathrm{~mL}$ by adding $7 \mathrm{~mL}$ of $2.4 \mathrm{M} \mathrm{HCl}$

(11) Dilute Folin-Ciocalteu reagent 5X (this is the working reagent)

\section{To measure free phenols}

(1) Pipette $20 \mathrm{uL}$ of sample into a clean cuvette and add $2000 \mathrm{uL}$ of dilute Folin

(2) Allow the reaction to proceed for $20 \mathrm{~min}$

(3) After $20 \mathrm{~min}$ read absorbance at $750 \mathrm{~nm}$

(4) Calculate concentration based on standard curve

\section{To measure total phenols}

(1) As before measure the absorbance at $750 \mathrm{~nm}$ of the hydro- 
lyzed sample plus Folin reaction mixture (before passing through polyclar)

(2) Also read the absorbance of the eluate plus Folin reaction mixture (after passing through polyclar)

(3) Subtract the reading of eluted sample (after polyclar) from the reading of hydrolyzed sample (before polyclar)

(4) Calculate concentration based on standard curve; include dilution factors in the calculation (Figure 2)

This procedure completely eliminates possible sugar interferences, ascorbic acid, any amino acids or proteins, and sulfate. Phenols were found to be $>99 \%$ removed by polyclar thus showing the applicability of the methodology. This method removes phenols from solutions ranging from $100 \%$ water to $100 \%$ methanol. Pure compounds at $100 \mu \mathrm{M}$ were tested and analyzed after column treatment by HPLC. Classes of polyphenols removed include phenolic acid (test sample ferulic acid), flavonols (quercetin), flavanols (catechin), flavanones (naringenin), flavone (flavone), isoflavones (genestein), anthocyanins (malvidin-3-O-glycoside).

\section{Miscellaneous Methods}

\section{Flow Injection Analysis}

Rangel et al. [25] published a multi-syringe flow injection analysis in food products using gallic acid as the standard. The sequence used was a single reagent methodology with 12 samples/hour capacity. The precision ranged from 0.34 to $1.33 \%$ for gallic acid standards of 40 and $2.5 \mathrm{mg} / \mathrm{L}$. There were no interferences with glucose, citric acid and sodium sulfite.

\section{Development of a mixed polyphenol standard}

Luthria and Vinyard [26] at the USDA in Beltsville proposed a 5 compound mixture of polyphenols as a reference standard for evaluating antioxidant activity of food extracts. The mixture is composed of commercially available caffeic acid, hesperetin, morin, catechin and epigallocatechin gallate. They were not combined in equal molar concentrations in the mixture. These compounds were stable in the solid when stored at 4oC for 3 months. They are currently being tested for assay of phenolics by the Folin method.

\section{Urinary analysis of polyphenols}

The most innovative use of the Folin assay has been accomplished by a Spanish group who have used it for the urine assay of polyphenol intake [27]. There have been sporadic reports of Folin assays in physiological fluids over the years but they have been largely discounted due to the large protein and small molecules such as ascorbate causing interference. These interferences are larger than the polyphenol concentrations from the diet which are probably less than $10 \mu \mathrm{M}$ in plasma and $100 \mu \mathrm{M}$ in urine. The authors used a solid phase extraction (Oasis HLB) to isolate and separate the polyphenols from interferences and then assayed by the two-step Folin (Fig 4). Creatinine was measured by alkaline picrate colorimetry. Recovery of 3 to $30 \mu \mathrm{M}$ catechin (the standard) was 83 to $107 \%$ with a precision averaging $4 \%$. There was an excellent correlation between epicatechin metabolites from human consumption of cocoa powder as measured by Folin and a LC/ MS method $(\mathrm{r}=0.83, \mathrm{p}<0.001)$.
The above method was also used with Gallic acid as the standard for urinary excretion of tomato juice polyphenols using a microplate reader for the Folin assay [28]. The latest methodology published by the same group was the use of the Folin combined with 96-well plate cartridges from Oasys to measure urinary total phenolic compounds as a biomarker of polyphenols intake [29]. This utilized spot urine sampled which positively correlated with polyphenol intake and fruit and vegetable intake. The cartridges reduced the analysis time from 11.5 to only 2 hours.

\section{Other References}

There have been a number of excellent articles comparing and criticizing the various colorimetric and antioxidant assays such as Folin, oxygen radical absorbance parameter, total radical trapping antioxidant parameter, trolox equivalent antioxidant capacity among others. They are listed in the reference section $[30,31,32,33,34,35]$. The results usually show a high degree of correlation between the methods indicating that no particular method is more valid. The Folin method is often criticized as giving higher values for polyphenols compared to the sum of the individual compounds as measured by HPLC as is the case for the flavonols (catechins) in chocolate [36]. However the oligomers and polymers contain multiple phenolic groups and oxidation of them may produce products that are themselves reducing agents thus giving a greater Folin value. This sequence can potentially occur in vivo and thus the Folin measurement may be relevant and it is easier, quicker and less expensive to do the laboratory. Epidemiological studies indicate certain food or class of polyphenol consumption was associated with a significant reduction in risk of chronic diseases such as heart disease, stroke and cancer [37]. No such association has been found for single polyphenol compounds, $20+$ of which now have been assayed in market foods and beverages by the USDA. This lack of association is because the polyphenols act in concert when plant foods are consumed thus validating the applicability of the antioxidant assays including the Folin reagent.

\section{References}

[1]. Folin O, Ciocalcuteu V. (1927) Tyrosine and tryptophan determinations in proteins. J. Biol. Chem. 73:627-650.

[2]. Singleton VL, Rossi JA. (1965) Colorimetry of total phenolics with phosphomolybdic-phosphotungstic acid reagents. Am. J. Enol. Vitic. 16:144158.

[3]. Singleton VL, Orthofer R, Lamuela-Raventos RM. (1999) Analysis of total phenols and other oxidation substances by means of Folin-Ciocalteu reagent. Methods Enzymol. 299:152-178.

[4]. Vinson JA, Su XH, Zubik L, Bose P. (2001) Phenol antioxidant quantity and quality in foods: fruits. J. Agric. Food. Chem. 49:5315-5321.

[5]. Vinson JA, Proch J, Bose P. (2001) Determination of quantity and quality of polyphenol antioxidants in foods and beverages. Methods Enzymol. 35:103-114

[6]. Vinson JA, Zubik L, Bose P, Samman N, Proch J. (2005) Dried fruits: excellent in vitro and in vivo antioxidants. Am. Coll. Nutr. 24:44-50.

[7]. Stratil P, Klejdus B, Kubán V. (2007) Determination of phenolic compounds and their antioxidant activity in fruits and cereals. Talanta 71:1741-1751.

[8]. Vinson JA, Hao Y, Su X. (1998) Phenol Antioxidant Quantity and Quality in Foods: Vegetables. J. Agric. Food Chem. 46:3630-3634.

[9]. Stratil P, Klejdus B, Kubán V. (2006) Determination of total content of phenolic compounds and their antioxidant activity in vegetables--evaluation of spectrophotometric methods. J. Agric. Food Chem. 54:607-616.

[10]. Vinson JA. (1998) Flavonoids in foods as in vitro and in vivo antioxidants. Adv. Exp. Med. Biol. 439:151-164.

[11]. Vinson JA, Liang X, Proch J, Hontz BA, Dancel J, et al. (2002) Polyphenol antioxidant in citrus juices: in vitro and in vivo studies relevant to heart disease In: Buslig BS, Manthey JA, editors. Flavonoids in Cell Function. New York. Kluwer Academic/Plenum Publishers, p 113-122.

[12]. Vinson JA, Bose P, Proch J, Al Kharrat H, Samman N. (2008) Cranberries and cranberry products: powerful in vitro, ex vivo, and in vivo sources of 
antioxidants. J. Agric. Food Chem. 56:5884-5891.

[13]. Vinson JA, Dabbagh YA. (1998) Tea phenols: antioxidant effectiveness of teas, tea components, tea fractions and their binding with lipoproteins. Nutr. Res. 18:1067-1075.

[14]. Bonita JS, Mandarano M, Shuta D, Vinson J. (2007) Coffee and cardiovascular disease: in vitro, cellular, animal, and human studies. J. Pharmacol. Res. 55:187-198.

[15]. Vinson JA, Hontz BA. (1995) Phenol Antioxidant Index: Comparative Antioxidant Effectiveness of Red and White Wines. J. Agric. Food Chem. 43:401-403.

[16]. Vinson JA, Mandarano M, Hirst M, Trevithick JR, Bose P. (2003) Phenol antioxidant quantity and quality in foods: beers and the effect of two types of beer on an animal model of atherosclerosis. J. Agric. Food Chem. 51:55285533.

[17]. Vinson JA, Proch J, Zubik L. (1999) Phenol antioxidant quantity and quality in foods: cocoa, dark chocolate, and milk chocolate. J. Agric. Food Chem. 47:4821-4824.

[18]. Agbor GA, Oben JE, Ngogang JY, Xinxing C, Vinson JA. (2005) Antioxidant capacity of some herbs/spices from Cameroon: a comparative study of two methods. J. Agric. Food Chem. 53:6819-6824.

[19]. Agbor GA, Vinson JA, Oben JE, Ngogang JY. (2007) In vitro antioxidant activity of three Piper species. J. Herb. Pharmacother. 7:49-64.

[20]. Vinson JA, Proch J, Bose P. (2001) MegaNatural ${ }^{\circledR}$ gold grapeseed extract: in vitro antioxidant and in vivo human supplementation studies. J. Med. Food 4:17-26.

[21]. Ainsworth AE, Gillespie KM. (2007) Estimation of total phenolic content and other oxidation substrates in plant tissues using Folin-Ciocalteu reagent. Nature Protocols 2:875-877.

[22]. Georgé S, Brat P, Alter P, Amiot MJ. (2005) Rapid determination of polyphenols and vitamin $\mathrm{C}$ in plant-derived products J. Agric. Food Chem. 53:1370-1373.

[23]. Hertog MGL, Hollman CH, Dini P, Venem J. (1992) Optimization of a quantitative HPLC determination of potentially anticarcinogenic flavonoids in vegetables and fruits. J. Agric. Food Chem. 40:1591-1598.

[24]. Nardini M, Cirillo E, Natella F, Scaccini C. (2002) Absorption of phenolic acids in humans after coffee consumption. J. Agric. Food Chem. 50:57355741.

[25]. Magalhães LM, Segundo MA, Reis S, Lima JL, Rangel AO. (2006) Automatic method for the determination of Folin-Ciocalteu reducing capacity in food products. J. Agric. Food Chem. 54:5241-5246.

[26]. Luthria DL, Vinyard BT. (2008) Development of a potential reference material for evaluating antioxidant activity. J AOAC Int. 91:506-510.

[27]. Roura E, Andrés-Lacueva C, Estruch R, Lamuela-Raventós RM. (2006) Total polyphenol intake estimated by a modified Folin-Ciocalteu assay of urine. Clin. Chem. 52:749-752.

[28]. Hussein L, Medina A, Barrionnevo A, Lammuela-Raventos RM, AndresLacueva C. (2008) Normal distribution of urinary polyphenol excretion among Egyptian males 7-14 years old and changes following nutritional intervention with tomato juice (Lycopersicon esculentum. Int. J. Food Sci. Nutr. 4:1-10.

[29]. Medina-Remón A, Barrionuevo-González A, Zamora-Ros R, Andres-Lacueva C, Estruch R, et al. (2009) Rapid Folin-Ciocalteu method using microtiter 96-well plate cartridges for solid phase extraction to assess urinary total phenolic compounds, as a biomarker of total polyphenols intake. Anal. Chim. Acta 634:54-60.

[30]. Niki E, Noguchi N. (2000) Evaluation of antioxidant capacity. What capacity is being measured by which method? IUBMB Life 50:323-329.

[31]. Niki, E. (2002) Antioxidant activity: are we measuring it correctly? Nutr. 18:524-525.

[32]. Sanchez-Moreno C. (2002) Review: Methods used to evaluate the free radical scavenging activity in foods and biological systems. Food Sci. Technol. Int. 8:121-137.

[33]. Prior RL, Wu X, Schaich K. (2005) Standardized methods for the determination of antioxidant capacity and phenolics in foods and dietary supplements. J. Agric. Food Chem. 53:4290-4302.

[34]. Huang D, Ou B, Prior RL. (2005) The chemistry behind dietary antioxidant capacity assays. J. Agric. Food Chem. 53:1841-1856.

[35]. Robbins RJ, Kwik-Uribe C, Hammerstone JF, Schmitz HH. (2006) Analysis of flavanols in foods: what methods are required to enable meaningful health recommendations? J. Cardiovasc Pharmacol. 47: 110-118.

[36]. Mursu J, Voutilainen S, Nurmi T, Tuomainen TP, Kurl S, et al (2008) Flavonoid intake and the risk of ischaemic stroke and CVD mortality in middleaged Finnish men: the Kuopio Ischaemic Heart Disease Risk Factor Study. Br. J. Nutr. 100:890-5.

[37]. Wang L, Lee IM, Zhang SM, Blumberg JB, Buring JE, et al (2009) Dietary intake of selected flavonols, flavones, and flavonoid-rich foods and risk of cancer in middle-aged and older women. Am. J. Clin. Nutr. 89:905-912. 